\title{
NIGER (GUIZOTIA ABYSSINICA L.) - A PROMISING RABI SEASON CROP UNDER RICE-FALLOW SYSTEM IN NORTH-EAST INDIA
}

\author{
Bhabesh Gogoi \\ Advanced Centre for Integrated Farming Systems Research, (AICRP on IFS under ICAR-IIFSR) \\ Assam Agricultural University, Jorhat, Assam, India
}

Received: 28.05.2021

Revised: 06.06.2021

Accepted: 12.06.2021

\begin{abstract}
Assam is one of the major niger producing sates of India. Wide spread rice fallow and retreating northeast monsoon are the advantages for cultivation of rabi niger crop in Assam. However, niger yield under rainfed situation of Assam decreases drastically for every 15 days delay in sowing of the crop from 15th November to 30th December. The highest seed ( $4.1 \mathrm{q} / \mathrm{ha}$ ) and stover (31.0 q/ha) yield could be obtained from 15th November sown crop. Nevertheless, sali rice is harvested late in Assam and so, delay sowing of next rabi crop leads to lower productivity of the crop. Application of 50\% recommended dose of fertilizers (RDF) along with 50\% nitrogen through FYM considerably increases yield attributing parameters that in the end maximize the stover and seed yield of niger crop. This can give 19.3 and 4.3\% increase in stover and seed yield of niger respectively, over RDF. Thus, half of chemical fertilizers required for niger crop could be substituted through organic nutrient sources, which has also lead to an improvement in soil physico-chemical properties and higher availability of nutrients in soil. This review reported the detail management strategies for successful cultivation of rabi niger crop under rainfed situation of Assam of North-East region of India.
\end{abstract}

Keywords: Niger crop, Rice fallow system, Cultivation practices, North-east India.

\section{INTRODUCTION}

Niger (Guizotia abyssinica L.), a minor oilseed crop, is suitable under rainfed, less fertile soil. Niger seed which can be used as a human food contains $37-47 \%$ oil. The oil is pale yellow in colour with a pleasant odour and taste is similar to desi ghee. The oil contains higher amount of unsaturated fatty acid (oleic acid 38\% and linoleic acid $51.6 \%$ ) and is free from toxins. The niger oil is having various uses viz., (i) the oil is used for culinary purposes; (ii) for lighting and as lubricating oil; (iii) manufacturing of paints and soft-soaps; (iv) in perfume industry, it is used as a base oil as because the niger oil is a good absorbent of fragrance of flowers; $(v)$ niger oil is having medicinal properties for which it is used for body massage and treatment of many diseases; (vi) niger seed cake is a valuable cattle feed particularly for milch cattle; (vii) niger seed cake can also be used as a manure. Besides, the crop can also be grown as green manure crop for increasing the soil productivity.
India rank first with a contribution of more than $50 \%$ of world niger area and production. It is cultivated in 4.37 lakh hectare area of the country with a production of 1.11 lakh tonnes (Ahlawat, 2010). With the area of 9.70 thousand hectare under niger crop, Assam is one of the major niger producing sates of India. For increasing niger production in Assam, a number of experiments were conducted at Assam Agricultural University (AAU), Jorhat and Regional Agricultural Research Station (RARS), AAU, Gossaigaon which reveals that the rabi niger crop fit well under ricefallow system in Assam of North-East Region (NER) of India.

Several factors lend credence to choose the niger crop by the farmers of Assam: (1) it can tolerance poor soil and drought, (2) animals do not relish it, (3) no serious pests and diseases are there so as to cause economic losses to the crop, and as such no plant protection measures are required under Assam condition (4) with vigorous growth habit, niger can

*Corresponding author: bg100777@yahoo.co.uk 
easily compete with annual weeds, (5) seeds can be stored for a year or more without deterioration, and (6) seeds mature 100-110 days after planting.

\section{Site selection and sowing of niger}

Niger can grow in a wide range of soil types, but cannot hold up well in water logging. The crop thrives best on silt loam to sandy loam soil with 5.2 to $7.3 \mathrm{pH}$ range. The crop can be cultivated in upland as well as in medium low-land with good drainage capacity. Niger crop sown after the harvest of sali rice by mid November can utilize the rainfall due to North-east monsoon in Assam. Growing of this second crop after rice improves the land use efficiency of a vast tract of rice fallow and adds organic matter to soil.

Sowing period for niger in different states in India varies depending of the climatic and geographical location (Table 1). Optimum sowing time for kharif niger is from mid of June to early August. However, farming community of Assam of NER of India prefers to cultivate niger as a rainfed rabi crop.

Table 1: Sowing time of niger in different states of India.

\begin{tabular}{|l|l|}
\hline State & Optimum time of sowing \\
\hline Andhra Pradesh & Second week of August \\
\hline Bihar & Second fortnight of August-September (After kharif crop) \\
\hline Karnataka & June-August \\
\hline Madhya Pradesh & Second-third week of July \\
\hline Maharashtra & \begin{tabular}{l} 
July to early September (after kharif crop) \\
\hline Orissa
\end{tabular} \\
$\begin{array}{l}\text { Third week of July - first week of August } \\
\text { Second fortnight of August-September (after kharif crop) }\end{array}$ \\
\hline
\end{tabular}

Niger varieties recommended for different states of India are shown in Table 2. Suitable varieties under Assam condition are- NG-1 (Local), GA-5 and KEC-3. Here, KEC-3 variety is recommended for Central Brahmaputra Valley Zone of Assam. Field for cultivation of niger crop should be prepared for fine tilth by 3-4 ploughings followed by laddering. Furrows of $5 \mathrm{~cm}$ depth were prepared at $25 \mathrm{~cm}$ apart and seeds were placed at $3-5 \mathrm{~cm}$ depth at the rate of $8 \mathrm{~kg} \mathrm{ha}^{-1}$. Then laddering was done along the furrows to cover the seeds with a soil layer of about 3-5 $\mathrm{cm}$ to ensure compaction of soil for getting quick and uniform germination. In case of broadcasting method of sowing, broadcasting should be uniform to get welldistributed plant population (Milli et al., 2012). However, this method requires a higher seed rate of $12 \mathrm{~kg} \mathrm{ha}^{-1}$ and this also creates difficulties in inter cultural operations. Hence, farmers are advised to follow the line method of sowing.

Table 2: Niger varieties recommended for different states of India.

\begin{tabular}{|l|l|}
\hline State & Variety \\
\hline Madhya Pradesh & $\begin{array}{l}\text { Birsa Niger-1, Birsa Niger-3, N-5, Ootacamund, Jawahar Niger } \\
\text { Composite-1, JNC-6, JNC-9, BNS-10 (Pooja-1) }\end{array}$ \\
\hline Andhra Pradesh & KRN-1 (No. 71), BNS-10 (Pooja-1), Birsa Niger-3 \\
\hline Bihar & BNS-10 (Pooja-1), Birsa Niger 1, N-5, Ootacamund \\
\hline West Bengal & KRN-1, Sahyadri, BNS-10 (Pooja-1), Birsa Niger-3 \\
\hline Orissa & $\begin{array}{l}\text { GA-10 (Shiva) (Deomali), Birsa Niger-3, Bhavani (GA-5), Sahyadri, } \\
\text { KRN-1, BNS-10 (Pooja-1), Utkal Niger-150 }\end{array}$ \\
\hline Rajasthan/Maharashtra/ Uttar Pradesh & IGPN-2004-1 (Phule Karala-1), Sahayadri (IGP-76), BNS-10 (Pooja-1) \\
\hline Karnataka & KBN-1, DNS-4, Shrilekha, BNS-10 (Pooja-1), IGPN-2004-1 \\
\hline Gujarat & RCR-317, BNS-10 (Pooja-1), Gujarat Niger-1, NRS-96-1 \\
\hline Tamil Nadu & Paitur-1, KRN-1, BNS-10 (Pooja-1) \\
\hline Assam & Local (NG-1), GA-5, KEC-3 \\
\hline
\end{tabular}




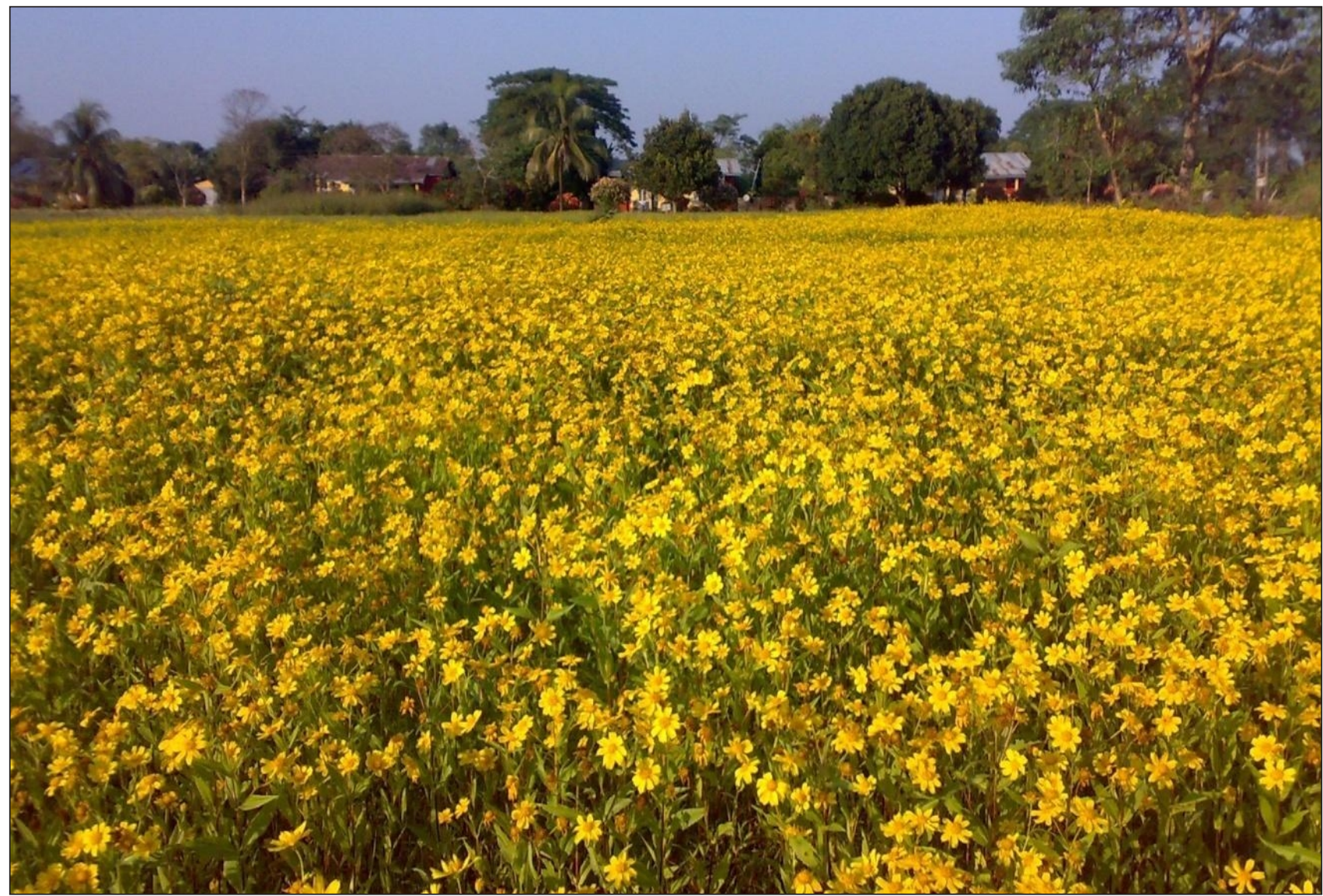

Image 1: An overview of the rabi niger (cv. NG-1) crop at RARS, AAU, Assam.

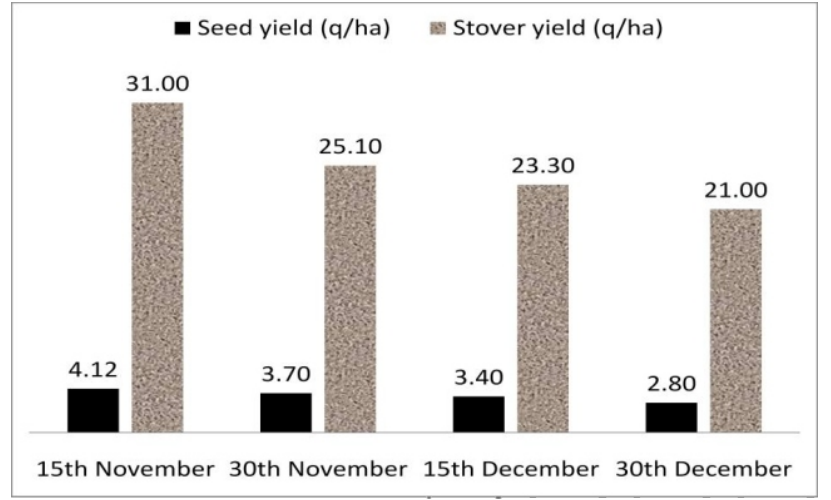

Fig. 1: Yield of niger as affected by date of sowing under Assam condition.

However, delay in sowing time of the crop decreases the growth and yield attributing character like plant height, number of branches per plant, number of capitula per plant, number of seeds per capitulum and 1000-seed weight of niger leading to low yield of the crop. From the Figure 1, it is explicit that the time of sowing is probably one of the main factors responsible for relatively higher niger yield from the sandy loam soil of Assam. The highest seed (4.12 q/ ha) and stover (31.0q/ ha) yield could be obtained from $15^{\text {th }}$ November sown crop (Milli et al., 2012). Niger yield under rainfed situation of Assam decreases drastically for every 15 days delay in sowing of the crop from $15^{\text {th }}$ November to $30^{\text {th }}$ December. Consequently, sowing of niger crop on first fortnight of November was found to be optimum under Assam condition in order to obtained higher yield of the crop (Milli et al., 2012).

\section{Intercultural operations}

In Assam, niger is generally grown either as pure crop, mixed or relay crop during rabi season. The recommended dose of $\mathrm{N}, \mathrm{P}_{2} \mathrm{O}_{5}$ and $\mathrm{K}_{2} \mathrm{O}$ for niger in Assam soil are 20, 10 and $10 \mathrm{~kg} \mathrm{ha}^{-1}$, respectively (Thakuria and Gogoi, 1992). These nutrients are to be applied in the form of Urea, SSP and MOP @ 44, 63 and $17 \mathrm{~kg} \mathrm{ha}^{-1}$ respectively as basal to the soil at the time of sowing. In case of line sowing, fertilizers can be applied in the furrows covering with a thin layer of soil just below the seeds.

Niger is fast growing and so its vigorous growth allows it to compete with annual weeds. However, all types of weeds should be removed before sowing of the seeds. During thinning operation (after 15-17 days of sowing) first 
weeding should be done. If necessary, a second weeding has to be done after 35 days of sowing.

In general, Niger is cultivated as rainfed crop in Assam. Nevertheless, irrigation must be given during vary dryspells especially at the seedling stage of the crop. As no serious pests and diseases have been observed, plant protection measures are not followed for niger crop in Assam. For enhancing yield through increased pollination and to get extra income, 5 honey bee colonies per hectare of niger is also recommended under the climatic condition of Assam.

\section{Niger crop after sali rice}

In Assam, with the advantage of considerable area under rice-fallow system as well as residual moisture in the field, a good rabi niger crop fits into the system. However, sali rice is harvested late in Assam and so, the sowing time of next rabi crop gets delayed that leads to lower productivity of the crop. Despite the fact that, there is a scope for increasing the niger production by proper nutrient management practices in rice- niger cropping sequence under rainfed situation of Assam.

For rice- niger cropping sequence in sandy loam soil of Assam, sali rice varieties suitable are- Satya and
Basundhara. These high yielding varieties are recommended for Assam particularly for using under multiple cropping systems. After the harvest of the rice, the niger crop (cv. NG-1) could be shown in the midst of November month. Study on influence of integrated nutrient management in case of niger (sown on $28^{\text {th }}$ November, 2011) conducted at Regional Agricultural Research Station, AAU, Gossaigaon, Assam revealed that application of 50\% recommended dose of fertilizers (RDF) along with 50\% nitrogen through FYM considerably increased yield attributing parameters that in the end maximizes the stover (29.00 q/ha) and seed (3.85 q/ha) yield of rabi niger (in Table 3) (Gogoi et al., 2010a; Gogoi et al., 2010b). Nutrient integrations i.e. 50\% RDF plus 50\% $\mathrm{N}$ through FYM application lead to an improvement in soil physicochemical properties and higher availability of nutrients in soil besides giving correspondingly 19.34 and 4.34\% increase in stover and seed yield of niger over recommended dose of fertilizers (Gogoi et al., 2010a). Thus, half of chemical fertilizers required for niger crop could be substituted through organic nutrient sources.

Use of biofertilizer based INM package (developed by Biofertilizer Section of AAU, Jorhat that includes Azotobacter + Phosphate Solubilizing Bacteria dual culture @ 3 kg/ha, application of FYM @ 3 tonne/ha, rock

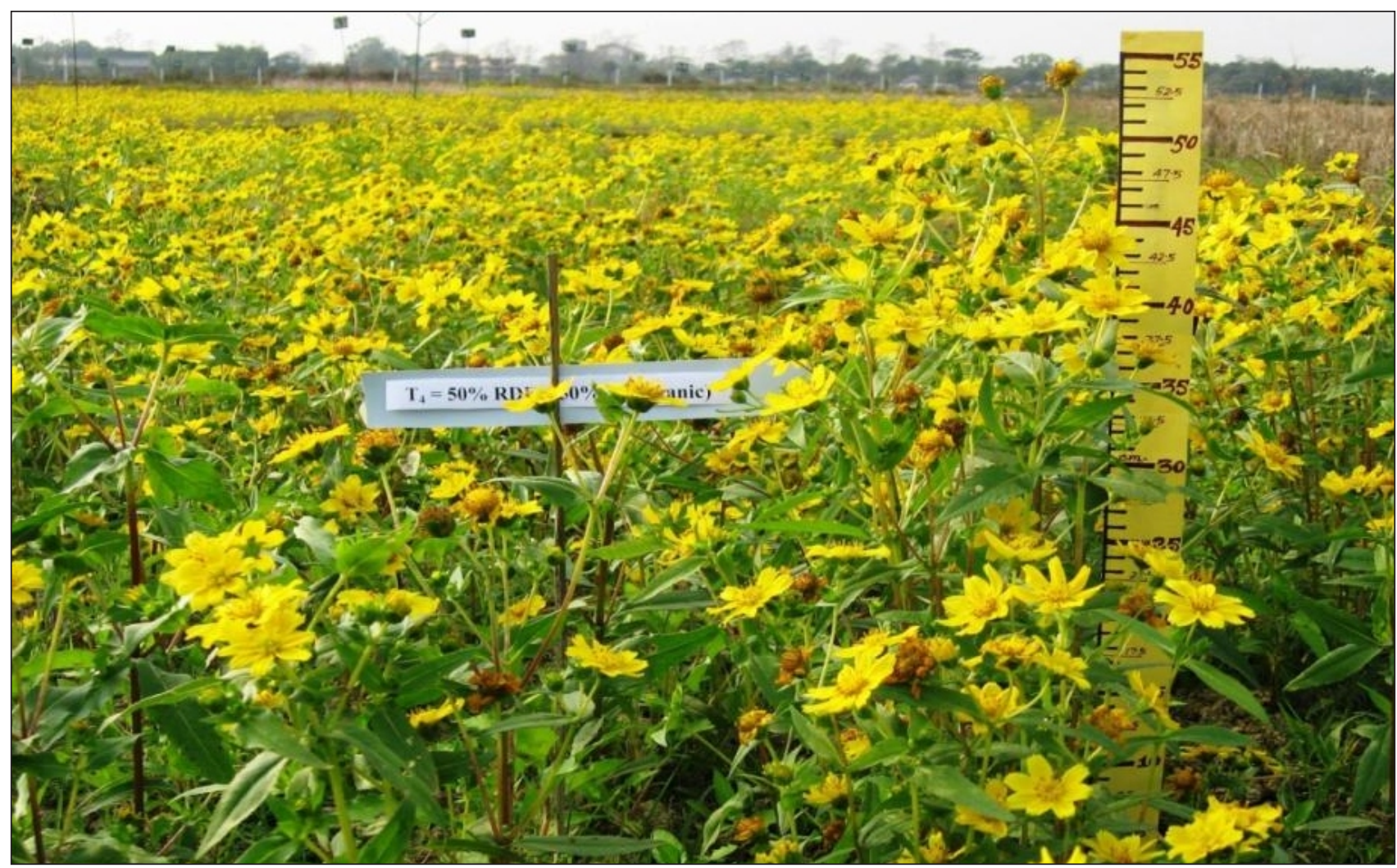

Image 2: Niger (cv. NG-1) crop in rice-fallow land with $50 \%$ RDF + 50\% N FYM. 
Table 3: Effect of INM on yield of late shown niger (cv. NG-1) after kharif rice in Assam

\begin{tabular}{|c|c|c|}
\hline \multirow[t]{2}{*}{ Treatments } & \multicolumn{2}{|c|}{ Yield of niger (q/ha) } \\
\hline & Seed & Stover \\
\hline Control (without fertilizers) & 1.70 & 11.92 \\
\hline Recommended dose of Fertilizers (RDF) & 3.69 & 24.30 \\
\hline Biofertilizer based INM package & 3.73 & 25.24 \\
\hline $50 \%$ RDF + 50\% N (FYM) & 3.85 & 29.00 \\
\hline $75 \%$ RDF + 25\% N (FYM) & 3.80 & 28.45 \\
\hline $50 \% \mathrm{~N}$ (inorganic) $+50 \% \mathrm{~N}(\mathrm{FYM})+\mathrm{PK}$ (inorganic and adjusted) & 3.77 & 27.22 \\
\hline 75\% N (inorganic) + 25\% N (FYM) + PK (inorganic and adjusted) & 3.62 & 23.78 \\
\hline
\end{tabular}

phosphate @ 50 per cent of recommended dose of $\mathrm{P}_{2} \mathrm{O}_{5}$, $\mathrm{K}_{2} \mathrm{O} @ 100$ per cent of recommended dose) also showed an increase in stover and seed yield of niger crop over RDF and control (Table 3). Biofertilizer based INM package might serves as a substrate to soil microbes resulting in the build up of their populations, besides sustaining the desired soil health and productivity for generations to come (Gogoi, 2011). Consequently after sali rice, nutrient management through organic (50\%) and inorganic (50\%) sources in case of rainfed niger crop found to be environmentally safe, economically viable and socially acceptable by the farming community of Assam.

\section{CONCLUSION}

Niger is suitable as rainfed crop and can grow in a wide range of soil types. In Assam, with the advantage of considerable area under rice-fallow system as well as residual moisture in the field, a good rabi niger crop fits into the cropping system. Optimum sowing time of niger in Assam is first fortnight of November which gives higher yield of the crop. However, sali rice is harvested late in Assam and so, the sowing time of next rabi crop gets delayed. Despite the fact that, there is a scope for increasing the niger production by proper nutrient management practices in rabi niger after the harvest of kharif rice in Assam. Here, 50\% recommended dose of inorganic fertilizers substituted through 50\% organic (FYM) sources of nutrients not only improves the physico-chemical and biological properties of soil but also considerably increases the yield of niger under rainfed condition of Assam.

\section{REFERENCES}

1. Ahlawat, I.P.S. (2010). Agronomy Rabi Crops: Niger. IARI, New Delhi. Pp.5. (nsdl.niscair.in> jspui> bitstream... appeared as on 10.10.2018).

2. Gogoi Bhabesh, Barua, N.G., Baruah, T.C. (2010a). Effect of integrated nutrient management on growth, yield of crops and availability of nutrients in inceptisol under rainfed rice (Oryza sativa)- niger (Guizotia abyssinica) sequence of Assam. Indian Journal of Agricultural Sciences, 80(9):56-60.

3. Gogoi Bhabesh, Barua, N.G., Baruah, T.C. (2010b). Influence of integrated nutrient management on crop yields in rainfed rice -niger cropping sequence. Oryza, 47(3): 221-226.

4. Gogoi Bhabesh. (2011). Soil properties and nutrients availability as affected by integrated nutrient management after rainfed cropping sequence. The Indian Journal of Agricultural Research, 45(4):346349.

5. Milli, R., Gogoi Bhabesh, Bora, P.C. (2012). Influence of time of sowing on yield and yield attributes of niger (Guizotia abyssinica L.) under rainfed situation of Assam. Agricultural Science Digest, 32(3):263-265.

6. Thakuria, K., Gogoi, P. K. (1992). Nutrient requirement of niger (Guizotia abyssinica Cass) under rainfed condition. Indian J. Agronomy, 37(3): 608610. 